\title{
UTJECAJ REKREACIJSKIH AKTIVNOSTI NA MENTALNO ZDRAVLJE
}

\author{
Ilija Marić ${ }^{1}$, Franjo Lovrić ${ }^{1}$, Darjan Franjiće,
}

${ }^{1}$ Fakultet prirodoslovno-matematičkih i odgojnih znanosti Sveučilišta u Mostaru,

${ }^{2}$ Klinika za onkologiju, Sveučilišna klinička bolnica Mostar

${ }^{3}$ Fakultet zdravstvenih studija Sveučilišta u Mostaru

88000 Mostar, Bosna i Hercegovina

Rad je primljen 13.09.2020.. Rad je recenziran 23.09.2020. Rad je prihvaćen 19.10.2020.

\section{SAŽETAK}

Rekreacijska aktivnost je složen pojam i često je povezana s ostalim potencijalno korisnim elementima kao što su socijalna interakcija, izloženost svježem zraku, boravak u prirodi. Tjelesna aktivnost ima važnu ulogu u poboljšanju psihičkog zdravlja. Procesi kojima rekreacijska aktivnost utječe na opću dobrobit i mentalno zdravlje su veoma složeni. Zbog toga je jako teško odrediti element ponašanja i aktivnost koja će sa sigurnošću donijeti korist u bavljenju fizičkom aktivnosti. Poticanje na fizičku aktivnost neizostavna je aktivnost brojnih zdravstvenih i odgojno-obrazovnih programa i ustanova, a podržavaju ih sve brojnija istraživanja koja svjedoče o pozitivnim efektima fizičke aktivnosti za osjećaj subjektivne dobrobiti. Znanstvenici pretpostavljaju da je zadovoljstvo životom povezano s fizičkom aktivnošću putem osjećaja samoefikasnosti i fizičkog samopouzdanja. Mnogi autori smatraju da rekreacijske aktivnosti pozitivno utječu na razinu samopouzdanja pojedinca te da rekreacijske aktivnosti pozitivno utječu na očuvanje mentalnog zdravlja kod osoba starije životne dobi. Tjelesna aktivnost i sposobnost sprječavaju pojavu različitih vrsta demencije. Smatra se da rekreacijske aktivnosti pozitivno utječu na svladavanje interpersonalnih vještina kod djece. U zdravih pojedinaca i osoba s invaliditetom tjelesna aktivnost utječe na manju podloženost stresu i depresiji. Tjelovježbu je moguće kombinirati s kognitivnom terapijom i terapijom lijekovima kod osoba koje su već oboljele od depresije. Redovito vježbanje i bavljenje sportom pozitivno povezano sa samopoštovanjem i samopoimanjem, a negativno je povezano sa stresom, anksioznošću i depresijom. Fizička aktivnost i tjelovježba korisne su u promociji pozitivne fizičke samopercepcije neovisno o spolu i dobnoj skupini. Cilj rada je na temelju dosadašnjih spoznaja analizirati utjecaj rekreacijskih aktivnosti na mentalno zdravlje.

Ključne riječi: utjecaj, rekreacija, aktivnost, mentalno zdravlje

Autor za korespondenciju:

Darjan Franjić, mag. rad. techn., doktorand

Email: darjan.franjic@fzs3.sum.ba 


\section{UVOD}

Tjelesna aktivnost, osim pozitivnog učinka na tjelesno zdravlje, ima važnu ulogu u poboljšanju psihičkog zdravlja. Danas se tjelovježba kao terapijsko sredstvo primjenjuje u velikom broju psihičkih poremećaja. Učinkovita je pri anksioznim poremećajima, depresiji, borbi protiv stresa, u liječenju psihotičnih poremećaja, demencije i dr. Osim izravnog učinka na neurotransmitorske sustave, endorfine i hormone, tjelovježbom se podižu samopoštovanje i samopouzdanje, poboljšavaju kognitivne funkcije i socijalizacija bolesnika. Prema preporukama Svjetske zdravstvene organizacije, potrebno je provoditi svakodnevnu tjelesnu aktivnost u trajanju od najmanje pola sata ili barem tri puta na tjedan u trajanju od jednog sata (1).

Tjelesna aktivnost ima veliku ulogu u poboljšanju života današnjeg suvremenog čovjeka, posebno u smislu očuvanja i poboljšanja psihofizičkog zdravlja. Potrebno je pronalaženje optimalnog načina tjelesnog vježbanja za pojedinca, tj. odabirom aktivnosti u kojoj uživa i kroz koju može smanjivati napetost i doživljeni stres. Značajni su pozitivni pomaci u zdravlju pojedinca pod utjecajem tjelesnog vježbanja, što se odnosi i na fizičku i na psihičku dobrobit pojedinca, što ukazuje na izravan utjecaj tjelesne aktivnosti na povećanje individualne kvalitete života. Do pozitivnih promjena u raspoloženju dolazi na multidimenzionalan način. Dolazi do fizioloških i biokemijskih promjena $\mathrm{u}$ organizmu, promjena $\mathrm{u}$ načinu mišljenja, doživljavanja sebe i okoline pod utjecajem tjelovježbe (2).

\section{ODNOS REKREACIJSKE AKTIVNOSTI I MENTALNOG ZDRAVLJA}

Održavanje normalnog ritma spavanja, veće samopoštovanje i samopouzdanje, bolje kognitivno funkcioniranje, bolje raspoloženje i stabilno mentalno zdravlje samo su neki od učinaka tjelesne aktivnosti na psihičko zdravlje čovjeka. Tjelesna je aktivnost pozitivno povezana s pozitivnim afektima, boljom percepcijom zdravlja te poboljšanom slikom o sebi. Iako su mnogi učinci tjelesne aktivnosti na psihičko zdravlje danas znanstveno dokazani, neki segmenti iz ove povezanosti i dalje su predmet istra- živanja i pronalaženja načina za unaprjeđenje tjelesnog i psihičkog u sinergiji. Iako postoje nesustavna iskustva u preporuci i izboru aktivnosti s obzirom na momentalno psihičko stanje vježbača, pravih pokazatelja o tome koja bi vrsta aktivnosti i pod kojim uvjetima bila najpogodnija za pojedine slučajeve za sada nema (3). Procesi kojima rekreacijska aktivnost utječe na opću dobrobit i mentalno zdravlje su veoma složeni. Zbog toga može biti jako teško točno odrediti element ponašanja i aktivnost koja će sa sigurnošću donijeti korist u bavljenju fizičkom aktivnosti. Rekreacijska aktivnost je složen pojam i često je povezana s ostalim potencijalno korisnim elementima kao što su socijalna interakcija, izloženost svježem zraku, boravak u prirodi. U istraživanjima koja se bave vezom tjelesne aktivnosti, povećanja opće dobrobiti i razine mentalnog zdravlja često je problem odrediti smjer djelovanja zbog pretpostavke da se osobe koje imaju višu razinu mentalnog zdravlja češće bave nekom tjelesnom aktivnosti. Povećanje fizičke aktivnosti rezultira povećanjem razine opće dobrobiti i otpornosti na mentalne zdravstvene poremećaje čime se ujedno povećava i motivacija za daljnjim sudjelovanjem u tjelesnim aktivnostima (4). U istraživanju Downwarda i Rasciutea dobiveno je da je bavljenje sportom pozitivno povezano sa subjektivnom dobrobiti, pri čemu sportovi u kojima su moguće socijalne interakcije s drugima, kao što su timski sportovi, dodatno doprinose većem osjećaju subjektivne dobrobiti (5). Slične rezultate dobili su Huang i Humpreys te Ruseski i sur. u kojima se pretpostavlja da fizička aktivnost doprinosi osjećaju subjektivne dobrobiti putem blagotvornog učinka na fizičko zdravlje $(6,7)$. U internacionalnoj studiji koja je obuhvatila preko 17000 ispitanika u dobi od 17 do 30 godina, nađeno je da postoji snažna pozitivna povezanost između zadovoljstva životom i fizičke aktivnosti. Uz to, oni sudionici koji su češće vježbali su izvještavali o većem zadovoljstvu životom od manje redovitih vježbača (8).

Schnohr i sur. su našli da što su osobe više fizički aktivne to su imale manje razine stresa te su iskazivale veće zadovoljstvo životom (9). U studiji Valoisa i sur. na uzorku srednjoškolaca, nađeno je da postoji statistički značajna negativna povezanost između 
fizičke neaktivnosti i zadovoljstva životom (10). U recentnome istraživanju Richardsonove i sur. u kojemu su prikupljeni podaci o tipu fizičke aktivnosti te učestalosti i trajanju fizičke aktivnosti, uspoređivali su se vježbači i ne-vježbači na mjerama anksioznosti, stresa i zadovoljstva životom. Nađeno je da osobe koje redovito vježbaju imaju niže razine stresa i anksioznosti, a više zadovoljstvo životom od osoba koje je ne vježbaju. No, navedeno se odnosi samo na aktivnosti šetanja, aerobika te timskih sportova. Naime, nije nađena statistički značajna razlika u razinama stresa, anksioznosti i zadovoljstva životom kod redovitih vježbača koji idu u teretanu, onih koji se bave trčanjem, borilačkim vještinama, plivanjem, jogom, jahanjem, vodenim aerobikom te ne-vježbača (11).

\section{UTJECAJ REKREACIJSKE AKTIVNOSTI NA SAMOPOUZDANJE}

Samopouzdanje je dio slike o sebi i odnosi se na procjenu vlastitih sposobnosti za obavljanje različitih zadataka ili oblika ponašanja (12). Odnos bavljenja sportom i samopoštovanja nastojala su objasniti mnoga istraživanja. Istraživanje koje su proveli Pastor i sur. pokazuje da je redovito vježbanje i bavljenje sportom pozitivno povezano sa samopoštovanjem, samopoimanjem i samoefikasnošću, a negativno povezano sa stresom, anksioznošću i depresijom (13). Coatsworth i Conroy u svome su istraživanju potvrdili povezanost više razine samopoštovanja i sudjelovanja u sportu (14). Posljednjih godina mnoga istraživanja nastojala su objasniti odnos bavljenja sporta i samopoštovanja. Tako neka od njih pokazuju da je redovito vježbanje i bavljenje sportom negativno povezano sa stresom, anksioznošću i depresijom, a pozitivno sa samopoštovanjem, samopoimanjem i samoefikasnošću (15). Sudjelovanje osnovnoškolske djece u sportskim aktivnostima povezano je sa kasnijim pozitivnim procjenama kao što je visoko samopoštovanje. Sportaši općenito pokazuju više samopoštovanje od nesportaša, odnosno sudjelovanje u sportu pridonosi izgradnji samopoštovanja što potvrđuju razna istraživanja (16-18). Harter nalazi da djeca sa višim sportskim samopoimanjem odnosno procjenom sebe kao uspješnima i kompetentnima u sportu imaju više samopoštovanje od onih sa manjim sportskim samopoimanjem (19). Sukladne nalaze dobili su i Weiss i Duncan (2003), čije je istraživanje pokazalo da djevojčice i dječaci koji se smatraju uspješnim u sportu percipiraju sebe dobro prihvaćenim među vršnjacima, te pokazuju veću razinu samopoštovanja (20). Iz istraživanja koja se bave ovim područjem može se zaključiti sljedeće:

- fizička aktivnost i tjelovježba korisne su u promociji pozitivne fizičke samopercepcije;

- 78 \% istraživanja koja se bave ovom problematikom pokazuju pozitivne promjene u samopouzdanju nakon fizičke aktivnosti;

- iako su dokazana poboljšanja, pola istraživanja ne može dokazati dugotrajnije pomake u samopouzdanju;

- pozitivni učinci dokazani su kod svih dobnih skupina;

- pozitivni učinci dokazani su kod oba spola;

- pozitivni rezultati više su vidljivi kod osoba s nižim samopouzdanjem;

- različite vrste fizičkih aktivnosti djeluju na razinu samopouzdanja (3).

\section{UTJECAJ REKREACIJSKE AKTIVNOSTI NA MENTALNO ZDRAVLJE ODABRANIH POPULACIJSKIH SKUPINA}

Rekreacijska aktivnost i mentalno zdravlje osoba starije životne dobi

Prva istraživanja o intervencijama vezanim za fizičku aktivnost osoba starije životne dobi počinju šezdesetih godina prošlog stoljeća, ali su karakterizirane brigom za sigurnost i zdravlje starijih osoba kao i skepticizmom oko njihove učinkovitosti. Zbog toga je ovo područje veoma sporo napredovalo. S vremenom se došlo do rezultata o različitim beneficijama fizičke aktivnosti za starije osobe. Provedena su sustavna istraživanja povezanosti između tjelesne aktivnosti i mjera ishoda kognitivne funkcije u gdje su rezultati uvjerljivo pokazali da je rizik od demencije i Alzheimerove bolesti smanjen u fizički aktivnim skupinama. Također, epidemiološke studije uglavnom podržavaju stav da tjelesna aktiv- 
nost i sposobnost sprječavaju pojavu različitih vrsta demencije i da vjerojatno imaju ulogu u očuvanju zdravlja mozga i optimalnog kognitivnog funkcioniranja (3). Močnik i sur. su proveli istraživanje na 38 ispitanika starije životne dobi kako bi ispitali njihov odnos prema fizičkoj aktivnosti. Podaci pokazuju da 28,9 \% ispitanika uopće ne vježba, a njih $36,8 \%$ vježba $2-3$ puta na tjedan, a $43,3 \%$ vježba svakodnevno. Većina njih koji vježbaju navodi da za vježbu izdvoje 30 minuta do najviše 1 sata. Veliki broj njih $(60,5 \%)$ nije upoznato s prednostima tjelesne aktivnosti, a njih 39,5\% kao prednosti navodi bolju pokretljivost, veće zadovoljstvo, samopouzdanje, sprečavanje osteoporoze, bolje psihofizičko stanje organizma, bolje raspoloženje te lakše svladavanje tjelesnih napora (21).

\section{Rekreacijska aktivnost i mentalno zdravlje radno aktivnog stanovništva}

Danas brojne tvrtke imaju razrađene različite vrste programa za unapređenje zdravlja od kojih se veliki dio temelji na promociji tjelesne aktivnosti u slobodnom vremenu. Glavni cilj sportsko-rekreacijskih programa za zaposlenike je unapređenje zdravlja kroz prevenciju, ublažavanje i otklanjanje tegoba te kompenzaciju i korekciju ostalih negativnih učinaka koji su posljedica različitih opterećenja na radnom mjestu. Na temelju klaster analize koju su proveli Jurakić i sur. zaposlenici i zaposlenice srednje dobi grupirani su u pet skupina homogenih prema obilježjima posla. Prema rezultatima navedenog istraživanja sportsko-rekreacijski programi skupini zaposlenika koji dominantno sjede na radnom mjestu trebali biti usmjereni na unapređenje sustava za prijenos kisika te jačanje i istezanje mišića cijelog tijela s naglaskom na mišićne grupacije leđa, trbuha i nogu.

Ciljevi sportsko-rekreacijskih programa za zaposlenike koji stoje bi trebali biti usmjereni na povećanje jakosti i izdržljivosti mišića nogu i lumbalnog dijela leđa te na aktivaciju sustava za prijenos kisika. Prilikom odabira aerobnih aktivnosti trebalo bi se opredijeliti za vožnju biciklom, veslanje ili plivanje, a izbjegavati aktivnosti koje se provode u stojećem položaju, kao što su hodanje, trčanje i rolanje (22).

\section{Rekreacijska aktivnost i mentalno zdravlje djece i mladih}

Tjelesna aktivnost je jedan od važnih čimbenika u očuvanju i unapređenju psihičkog i fizičkog zdravlja te važna pretpostavka za uspješnu provedbu različitih svakodnevnih aktivnosti i kvalitetniji život.

Znatan broj istraživanja upozorava na izravnu povezanost između tjelesne aktivnosti i boljeg rada mozga, što je i potvrđeno rezultatima o boljim ocjenama djece koja su u nastavi imala dodatne sate tjelesnog. Istraživanja pokazuju izraženu pozitivnu povezanost mentalnog zdravlja i bavljenja tjelesnom aktivnošću. Tjelesna aktivnost ima važnu razvojnu ulogu, psihološku, socijalnu i kognitivnu. Omogućuje učenje reguliranja emocija, djeca su mirnija i koncentriranija, uspješno svladavaju interpersonalne vještine i grade pozitivne odnose $s$ vršnjacima. Pozitivno utječe na psihološku dobrobit djece i mladih jer podižući samopoštovanje pomaže u stvaranju pozitivne slike o sebi te smanjuje psihosocijalnu anksioznost, stres i razvoj depresije (22).

Učenici koji se redovito bave tjelesnom aktivnošću lakše upijaju i zadržavaju nove informacije u odnosu na djecu koja su tjelesno neaktivna. Rezultati istraživanja na Američkom fakultetu sportske medicine pokazali su da su učenici četvrtih i petih razreda koji su najmanje deset minuta prije testa iz matematike trčali i intenzivno vježbali postigli bolje rezultate od onih koji su mirno sjedili prije testa. $U$ časopisu The Journal of Pediatrics objavljeni su podaci o istraživanju povezanosti ocjena iz engleskog jezika i matematike s tjelesnom formom i indeksom tjelesne mase svakog djeteta, koji su učinjeni na temelju standardiziranih rezultata školskih testova. Istraživanje pokazuje da je najveći učinak poticanja tjelesne aktivnosti kod djece i mladih ako se istovremeno pokrene nekoliko različitih tipova mjera:

- poticati više tjelesne aktivnosti na igralištu;

- omogućiti djeci odlazak biciklom u vrtić ili školu;

- povećati broj sati tjelesnog odgoja i učiniti potrebne izmjene u programu tjelesnog odgoja;

- poticati roditelje da djeci osiguraju više tjelesnih aktivnosti izvan programa vrtića/škole;

- potaknuti ravnatelje da vrtiće i škole promo- 
viraju kao zdrave ustanove koji potiče tjelesnu aktivnost (23).

Rekreacijska aktivnost i mentalno zdravlje osoba $\mathrm{s}$ invaliditetom

Osoba s invaliditetom je svaka osoba kod koje postoji tjelesno, osjetilno i mentalno oštećenje, koje za svoju posljedicu ima trajnu ili pak najmanje $12 \mathrm{mje}$ seci smanjenu mogućnost obavljanja osobnih potreba u svakodnevnom životu. Bavljenjem s različitim kineziološkim aktivnostima izvršava se direktan učinak na tjelesnu komponentu organizma invalidne osobe, ali i na psihološku komponentu (24).

Istraživanja pokazuju na velike mogućnosti sporta i sportske rekreacije, a naročito kada je u pitanju psihosocijalni tretman i resocijalizacija osoba $s$ invaliditetom, naročito ratnih veterana i vojnih invalida $(25,26)$. Prilikom završetka 51-tjednog programa sportske rekreacije dokazano je da su veterani koji su sudjelovali u programima znatno napredovali po svim parametrima kognitivnih funkcija (24). Da bi se što veći broj invalidnih osoba uključio u aktivno bavljenje sportom, potrebno je osigurati stručne kadrove jer fizička aktivnost invalidnih osoba predstavlja specifičnost u radu sa ovom populacijom. Utjecaj kinezioloških aktivnosti kod osoba s invaliditetom očituje se kroz pozitivan utjecaj na motoričke i funkcionalne sposobnosti, morfološke karakteristike, psihološke, sociološke i kognitivne značajke te pridonosi većoj neovisnosti osobe s invaliditetom, što je prediktor bolje kvalitete života. Bavljenje sportom je značajno povezano i to u pozitivnom smjeru sa svim domenama kvalitete života osoba s invaliditetom neovisno o kategoriji kojoj pripadaju (27). Tjelesna aktivnost u zaštiti i unapređenju zdravlja u osoba s invaliditetom ima preventivnu, transformacijsku, kurativnu i rehabilitacijsku ulogu. Ciljevi sporta za osobu sa invaliditetom, ne samo da su isti kao i za zdravu osobu već su i jače istaknuti razvijenjem natjecateljskog duha, samodiscipline, samopotvrđivanja i prijateljstva (28).

\section{UTJECAJ REKREACIJSKE AKTIVNOSTI NA ANKSIOZNOST I DEPRESIJU}

Istraživanja o tjelesnoj aktivnosti i depresiji datiraju još od 19.st. U nedavnim dekadama mnoga istraživanja dokumentiraju korist od vježbanja na raspoloženje kod zdravih i klinički depresivnih pojedinaca. Metodologija problema kod mnogih istraživanja čini interpretaciju i primjenu teškim. Unatoč metodoloških problema, većina istraživanja pokazuje da vježbanje ima psihološke i psihijatrijske koristi. U cjelini, istraživanja pokazuju da vježbanje ima najveću korist kod pojedinaca koji imaju veća psihološka oštećenja i onih koji su klinički depresivni, ali obje, i kliničke i nekliničke populacije, imaju koristi. Istraživanja kod klinički depresivne populacije uključuju i hospitalizirane i ambulantne pacijente. U hospitaliziranih depresivnih pacijenata dokazano je značajno smanjenje depresije kod pacijenata kojima je bilo propisano aerobno vježbanje, ali ne i u kontrolnoj grupi koja je sudjelovala u radnoj terapiji (3).

Tjelovježba poboljšava prijenos neurotransmitera koji pozitivno utječu na raspoloženje. Kod osoba koje imaju depresivne simptome lučenje serotonina i dopamina je smanjeno, stoga je tjelovježba prirodan način na koji se može potaknuti njihovo lučenje. Također, udruživanje u grupe omogućuje osobama koje pate od depresije uključivanje u društvo što stvara pozitivne osjećaje koji su upravo suprotni simptomima depresije. Istraživači navode da aerobna i anaerobna tjelovježba pozitivno utječu na smanjenje depresivnih simptoma. Određeni dokazi pak navode da je aerobna vježba bolja od anaerobne pri smanjenju simptoma depresije, ali naglašavaju važnost trajanja i intenziteta tjelovježbe. Za optimalne rezultate bitna je ustrajnost u tjelovježbi srednjeg do jakog intenziteta. Također, navode da tjelovježba ne utječe samo na smanjenje simptoma depresije kod zdravih pojedinaca već da ju je moguće kombinirati s kognitivnom terapijom i terapijom lijekovima kod osoba koje su već oboljele. Kako su lijekovi za depresiju uglavnom na bazi serotonina (koji se pojačano luči za vrijeme tjelovježbe) osobama koje redovito vježbaju moguće je smanjiti medikamentoznu te- 
rapiju. Takav pristup prepoznale su mnoge zemlje među kojima se najviše ističu Belgija i Velika Britanija. Naime, unutar psihijatrijskih ustanova uveli su obaveznu tjelovježbu od trideset minuta u manjim grupama. Pozitivan utjecaj primijećen je već nakon nekoliko mjeseci, a terapija lijekovima je smanjena (29).

Dok postoji popriličan broj dokaza koji svjedoče o pozitivnim fiziološkim posljedicama redovite fizičke aktivnosti, istraživački nalazi studija koje se bave odnosom fizičke aktivnosti i mentalnog zdravlja nisu tako jednoznačni. Rezultati nekih studija koje su provedene 80 -ih godina prošlog stoljeća, ali i onih ranijeg datuma upućuju na to da tjelovježba umjerenog i niskog intenziteta može imati povoljne učinke na raspoloženje i blagostanje, dok tjelovježba visokog intenziteta može rezultirati povećanjem napetosti, anksioznosti i umora (30). King i sur. nisu našli statistički značajne razlike u mjerama depresije, napetosti, blagostanja i raspoloženja kod sudionika koji su se u trajanju od 6 mjeseci bavili aerobnim treningom i sudionika koji su bili u kontrolnoj grupi (31). U istraživanjima u kojima je anksioznost promatrana kao crta ličnosti, rezultati nisu jednoznačni. U nekima je dobiveno povećanje (32), u nekima smanjenje anksioznosti $(33,34)$, a u nekoliko njih je utvrđen jednak efekt u smanjenju anksioznosti kod osoba koje vježbaju kao kod onih koje meditiraju (35). U nekima, pak, nisu dobivene razlike u mjerama anksioznosti s obzirom na tjelovježbu (36). Također, u nekim studijama je efekt smanjenja stresa i anksioznosti nađen samo kod muških ispitanika, ali ne i ženskih. Uz to, od studija koje su našle smanjenje anksioznosti u funkciji tjelovježbe, utvrđeno je da je jedina karakteristika tjelovježbe koja je bitna za rezultat - trajanje. Dugotrajna tjelovježba, u trajanju od 9 ili više tjedana je vodila do većih redukcija u anksioznosti (37). Unatoč nekim nekonzistentnim nalazima, znanstvenici se načelno slažu da tjelovježba ima anksiolitičke efekte, odnosno da je povezana s malim do umjerenim smanjenjem na mjerama anksioznosti. Uglavnom su ti efekti akutni, dobiveni neposredno nakon tjelovježbe, te $\mathrm{u}$ trajanju od 2 do 4 sata (38). U istraživanju Norrisa i sur. adolescenti su bili raspodijeljeni u 4 grupe: oni koji su trenirali
10 tjedana visokim intenzitetom, umjerenim intenzitetom, grupa koja se bavila treningom fleksibilnosti te kontrolna grupa. Po završetku su prikupljeni podaci za neke fiziološke i psihološke varijable (39). Nađeno je da su ispitanici koji su trenirali visokim intenzitetom imali najniže razine stresa, anksioznosti, depresije i hostilnosti od četiri grupe. Istraživanja upućuju na povezanost fizičke neaktivnosti s razvojem mentalnih poremećaja. Neke kliničke i epidemiološke studije su pronašle negativnu povezanost između redovite tjelovježbe te simptoma depresije i aksioznosti. Na primjer, nađeno je da postoji negativna povezanost između redovite tjelesne aktivnosti i prevalencije ozbiljne depresije, socijalne fobije i agorafobije, a korelacije su ostale statistički značajne i nakon kontroliranja sociodemografskih varijabli, samoizvještaja o fizičkim te komorbiditetnim psihičkim poremećajima (40).

\section{TJELOVJEŽBA I ZDRAVLJE: ISTRAŽIVANJA NA SVEUČILIŠTU U MOSTARU}

Na Sveučilištu u Mostaru provedena su brojna istraživanja koja su se bavila važnošću rekreativnih aktivnosti u raznim populacijskim skupinama. Babić i sur. u radu objavljenom 2019. godine navode da adekvatna tjelovježba pomaže u očuvanju dobrog zdravlja te da često ima pozitivan učinak u sprečavanju brojnih bolesti (41). U istraživanju objavljenom 2018. godine Katić i sur. zaključuju da aktivno sudjelovanje žena srednje životne dobi u plesnoj rekreativnoj aktivnosti pozitivno utječe na njihovu kvalitetu života i doprinosi doživljaju boljeg zadovoljstva životom (42). U preglednom radu objavljenom 2020. godine Markotić i sur. u zaključku navode da rekreacijsko trčanje predstavlja aktivnost koja je učinkovita u prevenciji i liječenju psiholoških bolesti (43). Iste godine objavljen je rad Ajtlbeza i sur. na temu prisutnosti psihičkih simptoma i razine samopoštovanja u rekreativnih plesača i neplesača u kojoj je ispitivano 310 ispitanika. Rezultati pokazuju da rekreativni plesači imaju veće samopoštovanje i manje psihičkih simptoma od neplesača, ali i da razlika u rezultatima nije statistički značajna (44). Rezultati istraživanja koje su proveli Ćerkez-Zov- 
ko i sur. pokazuju da kod muškaraca adolescentne dobi bavljenje sportom predstavlja zaštitni čimbenik naspram štetnog pijenja alkoholnih pića (45). U istraživanju provedenom 2018. godine Babić i sur. navode da studenti tjelesne kulture statistički značajno postižu niže rezultate na podskalama opsesivno kompulzivnih simptoma, interpersonalne vurnelabilnosti, depresivnosti, anksioznosti, agresivnosti, fobija i psihotičnih obilježja u odnosu na studente medicine (46). Lukanović i sur. su u istraživanju objavljenom 2020. godine došli do zaključka da aktivni sportaši pokazuju u značajno manjoj mjeri psihološke simptome i bolje mentalno zdravlje te da iskazuju veće zadovoljstvo kvalitetom života i višu razinu samopoštovanja u odnosu na studente Fakulteta zdravstvenih studija koji su predstavljali kontrolnu skupinu (47).

\section{ZAKLJUČAK}

Tjelesna aktivnost povećava razinu kvalitete života, utječe na psihološki status, te pozitivno utječe na socijalizaciju. Dob u kojoj djeca počinju s bavljenjem rekreativnim aktivnostima povezana je $s$ rezultatima tjelovježbe. Dosadašnja istraživanja izvještavaju o reduciranim simptomima anksioznosti, depresije te nižim razinama stresa kod osoba koje su fizički aktivne. Bavljenje tjelesnom aktivnosti povećava razinu samopoštovanja te pomaže pojedincu u stvaranju pozitivnije slike o sebi. Fizička aktivnost i tjelovježba korisne su u promociji pozitivne fizičke samopercepcije neovisno o spolu i dobnoj skupini. Sve navedene prednosti rekreativnih aktivnosti rezultat su utjecaja različitih fizioloških, psiholoških i bioloških mehanizama.

\section{LITERATURA}

1. Grošić V, Filipčić I. Tjelesna aktivnost u poboljšanju psihičkog zdravlja. Medicus. 2019;28(2):197-203.

2. Bungić $M$, Barić R. Tjelesno vježbanje i neki aspekti psihološkog zdravlja. Zbornik radova, Zagreb, Kineziološki fakultet. 2009;24(2):65-75.

3. Žigman A, Ružić L. Utjecaj tjelesne aktivnosti na raspoloženje - fiziološki mehanizmi. Hrvatski športskomedicinski vjesnik. 2008;23(2):75-
82.

4. Clow A, Edmunds S, editors. Physical activity and mental health. London: Human Kinetics; University of Westminster; 2013.

5. Downward P, Rasciute S. Does sport make you happy? An analysis of the well-being derived from sports participation. International review of applied economics. 2014; 25(3):331-348.

6. Huang H, Humphreys BR. Sports participation and happiness: eidence from US microdata. Journal of Economic Psychology. 2012;33(4):776793.

7. Ruseski JE, Humphreys BR, Hallman K, Wicker P, Breuer C. Sport participation and subjective well-being: instrumental variable results from German survey data. Journal of Physical Activity and Health. 2014;11(2):396-403.

8. Grant N, Wardle J, Steptoe A. The relationship between life satisfaction and health behavior: a cross-cultural analysis of young adults. International journal of behavioral medicine. 2009;16(3):259-268.

9. Schnohr P, Kristensen TS, Prescott E, Scharling H. Stress and life dissatisfaction are inversely associated with jogging and other types of physical activity in leisure time-the Copenhagen city heart study. Scandinavian Journal of Medicine \& Science in Sports. 2005;15:107-112.

10. Valois RF, Zullig KJ, Huebner ES, Drane JW. Physical activity behaviors and perceived life satisfaction among public high school adolescents. Journal of school health. 2004;74(2):5965.

11. Richardson CR, Faulkner G, McDevitt J, Skrinar GS, Hutchinson DS, Piette JD. Integrating physical activity into mental health services for persons with serious mental illness. Psychiatr Serv. 2005 Mar;56(3):324-31.

12. Grgin Lacković K. Samopoimanje mladih. Jastrebarsko: Naklada Slap; 1994.

13. Pastor Y, Balaguer I, Pons D, García-Merita M. Testing direct and indirect effects of sports participation on perceived health in Spanish adolescents between 15 and 18 years of age. J Adolesc. 2003 Dec;26(6):717-30. 
14. Coatsworth JD, Conroy DE. Enhancing the seIf-esteem of youth swimmers through coach training: Gender and age effects. Psychology of Sport and Exercise. 2006;7(2):173-192.

15. Bowker A. The relationship between sports participation and self-esteem during early adolescence. Canadian Journal of Behavioural Science. 2006;38(3):214-229.

16. McAuley E, Elavsky S, Motl RW, Konopack JF, $\mathrm{Hu}$ L, Marquez DX. Physical activity, self-efficacy, and self-esteem: longitudinal relationships in older adults. J Gerontol B Psychol Sci Soc Sci. 2005 Sep;60(5):268-75.

17. McGee R, Williams S, Howden-Chapman P, Martin J, Kawachi I. Participation in clubs and groups from childhood to adolescence and its effects on attachment and self-esteem. J Adolesc. 2006 Feb;29(1):1-17.

18. Slutzky C, Simpkins S. The link between children's sport participation and self-esteem: Exploring the mediating role of sport self-concept. Psychology of Sport and Exercise. 2009;10(3):381-389.

19. Harter S. The construction of the self. A developmental perspective. London; The Guilford Press: 1999.

20. Weiss MR, Duncan SC. The relationship between physical competence and peer acceptance in the context of the children's sports participation. Journal of Sport \& Exercise Psychology. 1992;14:177-191.

21. Močnik A, Neuberg M, Canjuga I. Tjelesna aktivnost starijih osoba smještenih u stacionarnim ustanovama. Tehnički glasnik. 2015;9(1):112119.

22. Jurakić D, Andrijašević M, Pedišić Ž. Osnove strategije za unapređenje tjelesne aktivnosti i zdravlja zaposlenika srednje dobi s obzirom na obilježja radnog mjesta i skolnosti ka sportsko-rekreacijskim aktivnostima. Sociologija i prostor [Internet]. 2010 [pristupljeno 28.10.2020.];48(1 (186)):113-131. Dostupno na: https://hrcak.srce.hr/5544

23. Škes M. Utjecaj tjelesne aktivnosti na školski uspjeh. Nastavni zavod za javno zdravstvo "Dr.
Andrija Štampar" [Internet]. 2006 [pristupljeno 31.10.2020];15-19. Dostupno na:

http://www.stampar.hr/sites/default/files/Nabava/2016/node/add/dokumenti/utjecaj_tjelesne_ aktivnosti_na_skolski_uspjeh.pdf

24. Bartoš A. Sociološko- kineziološki pristup sportskoj rekreaciji u resocijalizaciji osoba s invaliditetom. Media, culture and public relations. 2006;7(1):71-78.

25. Xu X, Ozturk OD, Turk MA, McDermott SW. Physical Activity and Disability: An Analysis on How Activity Might Lower Medical Expenditures. J Phys Act Health. 2018 Aug 1;15(8):564571.

26. Vasudevan V, Bouldin E, Bloodworth S, Rocafort L. Likelihood of Meeting Physical Activity Guidelines of Veterans Who Are Obese by Disability Status. Am J Health Promot. 2019 Nov;33(8):1194-1199

27. Crnković I, Rukavina M. Sport i unapređenje kvaliteteživota kod osoba sinvaliditetom. Hrvatska revija za rehabilitacijska istraživanja [Internet]. 2013 [pristupljeno 28.10.2020.];49(1):1224. Dostupno na: https://hrcak.srce.hr/104207.

28. Idžanović A. Kvaliteta života sportaša s invaliditetom [Završni rad]. Osijek: Sveučilište Josipa Jurja Strossmayera u Osijeku, Filozofski fakultet; 2014 [pristupljeno 28.10.2020.] Dostupno na: https://urn.nsk.hr/urn:nbn:hr:142:104206

29. Biddle SJ, Mutrie N. Psychology of physical activity: Determinants, well-being and interventions. 2nd edition. Routledge; 2007.

30. Paluska SA, Schwenk TL. Physical activity and mental health: current concepts. Sports Med. 2000 Mar;29(3):167-80.

31. King AC, Taylor CB, Haskell WL,DeBusk RF. Influence of regular aerobic exercise on psychological health: A randomized, controlled trial of healthy middle-aged adults. Health Psychology. 1989;8(3):305-324.

32. Stern MJ, Cleary P. National exercise and heart disease project: Psychosocial changes observed during a low-level exercise program. Arch Intern Med. 1981;141(11):1463-1467.

33. Schwartz GE, Davidson RJ, Goleman DJ. Patterning of cognitive and somatic processes in the 
self-regulation of anxiety: Effects of meditation versus exercise. Psychosomatic Medicine. 1978;40(4):321-328.

34. Pauly JT, Palmer JA, Wright CC, Pfeiffer GJ. The effect of a 14-week employee fitness program on selected physiological and psychological parameters. J Occup Med. 1982 Jun;24(6):457-63.

35. Bahrke MS, Morgan WP. Anxiety reduction following exercise and meditation. Cogn Ther Res. 1978;2:323-333.

36. Thome J, Espelage DL. Relations among exercise, coping, disordered eating, and psychological health among college students. Eat Behav. 2004 Nov;5(4):337-51.

37. Taylor AH. Physical activity, stress and anxiety: A Review. In: Biddle SJH, Fox K, Boutcher S, editors. Physical activity and psychological well-being. London: Routledge; 2000. p. 10-45.

38. Petruzzello SJ. Anxiety reduction following exercise: methodological artifact or "real" phenomenon? Journal of Sport and Exercise Psychology. 1995;17(1):105-111.

39. Norris R, Carroll D, Cochrane R. The effects of physical activity and exercise training on psychological stress and well-being in an adolescent population. Journal of Psychosomatic Research. 1992;36(1):55-65.

40. Ströhle A. Physical activity, exercise, depression and anxiety disorders. Journal of neural transmission. 2009;116(6):777-784.

41. Babić M, Čerkez Zovko I, Tomić V, Perić O. Tjelovježba tijekom i poslije trudnoće. Zdravstveni glasnik [Internet]. 2019 [pristupljeno 29.10.2020.];5(2):53-65. Dostupno na: https:// hrcak.srce.hr/index.php?show=clanak\&id clanak jezik=332889
42. Katić S, Kvesić M, Lukanović B, Babić M. Učinak tjelovježbe na kvalitetu života žena srednje životne dobi. Zdravstveni glasnik [Internet]. 2018 [pristupljeno 29.10.2020.];2:25-32. Dostupno na: https://fzs.sum.ba/sites/default/files/ Glasnik\%202-2018.pdf

43. Markotić V, Pokrajčić V, Babić M, Radančević D, Grle M, Miljko M, et al. The positive effects of running on mental health. Psychiatr Danub. 2020 Sep;32(Suppl 2):233-235.

44. Ajtlbez L, Babić D, Franjić D, Barać K, Martinac M, Haxhibeqiri SS. Psychic symptoms and self-esteem in dancers. Psychiatr Danub. 2020 Sep;32(Suppl 2):244-253.

45. Cerkez I, Culjak Z, Zenic N, Sekulic D, Kondric M. Harmful alcohol drinking among adolescents: The influence of sport participation, religiosity, and parental factors. Journal of Child \& Adolescent Substance Abuse. 2015;24(2): 94101.

46. Babić M, Čerkez Zovko I, Martinac M, Babić R, Katić S, Lukanović B. Povezanost tjelovježbe i duševnog zdravlja studenata. Zdravstveni glasnik [Internet]. 2018 [pristupljeno 28.10.2020.];2:33-43. Dostupno na: https://fzs. sum.ba/sites/default/files/Zdravstveni $\% 20 \mathrm{gla}$ snik\%202018,\%20November,\%20No.\%208 0 . pdf $\#$ page $=35$

47. Lukanović B, Babić M, Katić S, Čerkez Zovko I, Martinac M, et al. Mental Health and SeIf-Esteem of Active Athletes. Psychiatr Danub. 2020 Sep;32(Suppl 2):236-243. 


\title{
THE IMPACT OF RECREATIONAL ACTIVITIES ON MENTAL HEALTH
}

\author{
Ilija Marić1, Franjo Lovrić ${ }^{1}$, Darjan Franjićc ${ }^{2,3}$ \\ ${ }^{1}$ Faculty of Science and Education University of Mostar, \\ ${ }^{2}$ Clinic for Oncology University Clinical Hospital Mostar \\ ${ }^{3}$ Faculty of Health Studies University of Mostar \\ 88000 Mostar, Bosnia and Herzegovina
}

\begin{abstract}
Recreational activity is a complex concept that is often associated to potentially useful elements such as social interaction, exposure to fresh air, or outdoor exercise. Physical activity plays an important role in the improvement of mental health. Processes of recreational activity affecting the overall well-being and mental health are very complex. Therefore, it is very difficult to determine the element of behaviour and activity that will certainly benefit engagement in physical activity. Encouraging physical activity is an indispensable action of many health and educational programmes and institutions, and they are supported by an increasing number of studies that show evidence of the positive effects of physical activity on the feeling of subjective well-being. Scientists suggest that life satisfaction is associated with physical activity through a sense of self-efficacy and physical self-confidence. Many authors believe that recreational activities have a positive effect on the level of self-confidence of the individual and that recreational activities have a positive effect on maintaining mental health in the elderly. Physical activity and ability prevent the onset of different types of dementia. It is considered that recreational activities have a positive effect on mastery of intrapersonal skills in children. In healthy individuals and people with disabilities, physical activity reduces the susceptibility for stress and depression. Exercise can be combined with cognitive and drug therapy in people who already suffer from depression. Regular exercise and sports are positively associated with self-esteem and self-perception but negatively associated with stress, anxiety and depression. Physical activity and exercise are useful in promoting positive physical self-perception regardless of gender and age. The objective of this study is to analyse the impact of recreational activities on mental health on the basis of the current scientific knowledge.
\end{abstract}

Key words: impact, recreation, activity, mental health

Correspondence:

Darjan Franjić, MA

E-mail: darjan.franjic@fzs3.sum.ba 